\title{
Melatonin Stimulates Activities and Expression Level of Antioxidant Enzymes and Preserves Functionality of Photosynthetic Apparatus in Hickory Plants (Carya cathayensis Sarg.) under PEG-Promoted Drought
}

\author{
Junfeng Wang ${ }^{1, \dagger}{ }^{\dagger}$ Juanjuan Chen ${ }^{1,+}$, Anket Sharma ${ }^{1,+} \oplus$, Shenchen Tao ${ }^{1}$, Bingsong Zheng ${ }^{1}{ }^{\circledR}$, \\ Marco Landi ${ }^{2,3,4}\left(\mathbb{D}\right.$, Huwei Yuan ${ }^{1, *}$ and Daoliang Yan ${ }^{1, *}$ \\ 1 State Key Laboratory of Subtropical Silviculture, Zhejiang A\&F University, Hangzhou 311300, China; \\ 2017702431011@stu.zafu.edu.cn (J.W.); 2017102202006@stu.zafu.edu.cn (J.C.); \\ anketsharma@gmail.com (A.S.); 2018102201004@stu.zafu.edu.cn (S.T.); bszheng@zafu.edu.cn (B.Z.) \\ 2 Department of Agriculture, Food and Environment, University of Pisa, 54124 Pisa, Italy; \\ marco.landi@unipi.it \\ 3 CIRSEC, Centre for Climatic Change Impact, University of Pisa, 54124 Pisa, Italy \\ 4 Nutrafood Research Center, University of Pisa, 54124 Pisa, Italy \\ * Correspondence: hwyuan@zafu.edu.cn (H.Y.); liangsie@zafu.edu.cn (D.Y.); Tel.: +86-(0)571-63732738 (H.Y.); \\ +86-(0)571-63732761 (D.Y.) \\ $+\quad$ The authors contributed equally to this article.
}

Received: 21 September 2019; Accepted: 29 October 2019; Published: 31 October 2019

\begin{abstract}
Nowadays, drought is one of the major abiotic factors which negatively affects growth and development of several fruit tree species, including Chinese hickory plants (Carya cathayensis Sarg.). The present investigation was conducted to study the possible positive effects of melatonin in drought resistance of $C$. cathayensis plants along with associated mechanisms. It was observed that melatonin pre-treatment applied before limited water availability significantly contrasted drought-promoted negative effects in terms of plant growth and physiological responses. Significant improvement was observed in key biological parameters like relative water content, net photosynthetic rate, stomatal conductance, transpiration rate, maximum photosynthetic efficiency of photosystem II (PSII), and PSII electron transport rate. Antioxidant apparatus was also stimulated by melatonin and enhanced activities of superoxide dismutase (SOD), catalase (CAT), and ascorbate peroxidase (APX) were noticed along with higher accumulation of proline. Gene expression studies herein revealed that melatonin promoted the up-regulation of the expression of SOD (70.7\%), CAT (32.7\%), and APX (66.5\%) genes. As a consequence, accumulation of malondialdehyde by-products and leaf symptoms were reduced in melatonin-treated plants. All these observations offer the clear evidence that pre-treatment with melatonin ameliorate the performance of Chinese hickory plants against drought stress.
\end{abstract}

Keywords: antioxidant system; hickory plant; reactive oxygen species; water stress

\section{Introduction}

Carya cathayensis Sarg. (Chinese hickory) is a nut tree, native to eastern China and mainly distributed around Tianmu Mountains in southern Anhui province and northeast Zhejiang province. The oil content of Chinese hickory kernel is up to $70 \%$, and the oil is rich in unsaturated fatty acids with high nutritional value, making it one of the most economically important trees of China [1,2]. 
Drought is one of the major abiotic stresses which limits crop yield and plant development [3,4]. Drought stress typically reduces the relative water content (RWC) and total chlorophyll content in leaves [5]. The decline in RWC of plant tissue limits directly the overall plant growth and causes toxicity to plant cells [6]. Drought also negatively affects the photosynthetic process of plants [7] by limiting stomatal function and disrupting normal functioning of photosystems, particularly photosystem II (PSII) [8]. Additionally, drought triggers non-stomatal limiting factors and redox imbalance in leaf cells, which also contribute in altering the photosynthetic process in plants under limited water availability [9]. Redox imbalance due to drought causes oxidative damage in plant cells [10]. The main cause of oxidative stress is the over production and accumulation of reactive oxygen species (ROS) in plants cells under abiotic stresses, including drought [10-14]. However, plants try to overcome the excessive accumulation of ROS by activation of their antioxidative system, which is composed by both enzymatic and non-enzymatic components [15-19]. Drought stimulates the activities of antioxidant enzymes like superoxide dismutase (SOD), catalase (CAT), ascorbate peroxidase (APX), and peroxidase (POD) [20-22]. Additionally, non-enzymatic antioxidants are also stimulated under drought conditions to preserve plant functionality [23].

Polyethylene glycol (PEG) is used to simulate a condition of drought in experimental studies and, at the same time, PEG molecules with molecular weight greater than 3000 are not absorbed by plant cells [24] thereby avoiding toxic side effects [25]. Melatonin is a multifunctional biomolecule and exerts multiple physiological and biochemical functions in plants [26-28]. Moreover, melatonin application has been shown to promote the plant resistance against a plethora of abiotic stress conditions such as salinity [29,30], drought [31,32], low temperature [33], boron [34,35], and heavy metal toxicity [36]. Melatonin can also improve the net photosynthetic rate of plants under various abiotic stresses, principally by maintaining the function of PSII and protecting chlorophyll molecules from degradation [26]. This reduction is attributable to the decline in oxidative stress accompanied by a lower level of cell damage and cell wall peroxidation [37,38]. Additionally, melatonin promotes the scavenging of ROS in plants under stress conditions by modulating the activities of antioxidants $[39,40]$ via up-regulating the expression of related genes [29].

In view of the ameliorative roles of melatonin in plants under stress, in the present study, leaves of Chinese hickory seedlings were pretreated with melatonin solutions before being subjected to PEG-induced drought stress. To explore the possible role exerted by melatonin, physiological (gas exchange and chlorophyll fluorescence analyses), biochemical (pigment, malondialdehyde (MDA) and proline (Pro) concentration, activity of SOD, CAT, APX), and molecular aspects related to antioxidant enzymes (expression of $S O D, C A T$, and $A P X$ genes) were studied under drought stress.

\section{Materials and Methods}

\subsection{Plant Material}

The current study was conducted in the greenhouse of Zhejiang Agriculture and Forestry University $\left(\mathrm{N} 30^{\circ} 23^{\prime}, \mathrm{E} 119^{\circ} 72^{\prime}\right)$, Hangzhou, China, from June to November of 2018. The growth conditions were: $25-35^{\circ} \mathrm{C}, 70 \%$ (relative humidity), and 12:12 h (light:dark photoperiod). Seedlings of C. cathayensis Sarg. (one-year-old) were transplanted in plastic pots with an inner diameter of $13 \mathrm{~cm}$ and height of $17 \mathrm{~cm}$. Pots were filled with mixture of soil (clay) vermiculite and perlite (4:3:1), and the field water holding capacity of $80 \%$ was maintained.

\subsection{Experimental Setup}

Before the beginning of the experiment, Chinese hickory plants were sprayed with five different concentrations of melatonin: $0,25,50,100$, and $200 \mu \mathrm{M}$. Melatonin spraying on leaves of Chinese hickory was done (once) every day for five consecutive days. The net photosynthetic rate of plants was measured on the second day after the last spray. On the basis of preliminary experiments, $100 \mu \mathrm{M}$ concentration of melatonin was selected for final experimentation. Experimental plants were divided 
into two groups, which were sprayed with distilled water and $100 \mu \mathrm{M}$ melatonin (once) every day for five consecutive days. Each treatment included three set of seedlings (each set was comprised of three pots with one seedling in each pot). Subsequently, the plants were subjected to drought stress the day after the last spray with distilled water or $100 \mu \mathrm{M}$ melatonin. Drought stress was induced by using a PEG-6000 solution supplied with a half strength (1/2) Hoagland's nutrient solution [41]. In total, there were eight treatment groups in this experiment: (1) Adequate moisture (CK), (2) mild drought stress (P1) 1/2, i.e., Hoagland nutrient solution with 15\% PEG concentration, (3) moderate drought stress (P2) 1/2, Hoagland nutrient solution with 25\% PEG concentration, (4) severe drought stress (P3) 1/2, Hoagland nutrient solution with 35\% PEG concentration, (5) adequate moisture + melatonin pretreatment (M), $100 \mu \mathrm{M}$ melatonin, (6) $15 \%$ PEG + $100 \mu \mathrm{M}$ melatonin (M-P1), (7) $25 \%$ PEG + $100 \mu \mathrm{M}$ melatonin (M-P2), (8) $35 \%$ PEG + $100 \mu \mathrm{M}$ melatonin (M-P3).

\subsection{Determination of Leaf Gas Exchange Parameters}

The net photosynthetic rate $(\mathrm{Pn})$, transpiration rate (Tr), stomatal conductance (Cond), and intercellular carbon dioxide concentration (Ci) of first, second, and third fully-expanded leaves (from the top) were measured by a Li-6400 portable photosynthesis measurement system (LICOR, Lincoln, NE, USA). Light intensity was $1260 \mu \mathrm{mol} \mathrm{m}{ }^{-2} \mathrm{~s}^{-1}, \mathrm{CO}_{2}$ concentration was $400 \mu \mathrm{mol}\left(\mathrm{CO}_{2}\right)$ $\mathrm{mol}^{-1}$, leaf chamber temperature was $25^{\circ} \mathrm{C}$, relative humidity was $60 \%$, and each measurement was repeated three times. Some other parameters like water use efficiency (WUE) and stomatal limiting factor $(\mathrm{Ls})$ were calculated as WUE $=\mathrm{Pn} / \mathrm{Trmmol}, \mathrm{Ls}=1-(\mathrm{Ci} / \mathrm{Ca})\left(\mathrm{Ca}=\operatorname{ambient} \mathrm{CO}_{2}\right)$.

\subsection{Determination of Chlorophyll Fluorescence}

Portable pulse-modulated chlorophyll fluorescence fluorometer (pam-2500, Walz, Germany) was used to measure chlorophyll fluorescence parameters. Chlorophyll fluorescence parameters were measured in homogeneous top fully-expanded leaves used for gas exchange determinations. First, a dark adaptation clip was placed on the leaf, and the values of Fo and Fm were measured in dark-adapted leaves (30 min) before and after a saturating pulse $\left(8000 \mu \mathrm{mol} \mathrm{m}^{-2} \mathrm{~s}^{-1}\right.$ for $\left.1 \mathrm{~s}\right)$, whilst the maximal PSII photochemical efficiency $[\mathrm{Fv} / \mathrm{Fm}=(\mathrm{Fm}-\mathrm{Fo}) / \mathrm{Fm}]$ and the operating PSII efficiency $\left[\mathrm{Y}(\mathrm{II})=\left(\mathrm{Fm}^{\prime}-\mathrm{Fs}\right) / \mathrm{Fm}^{\prime}\right]$ were calculated according to [9]. $\left(\mathrm{Fm}^{\prime}=\right.$ maximum Chl flurorescence in the light-adapted state, Fs = steady state Chl fluorescence).

\subsection{Relative Water Content of Leaves}

The fresh leaves (three leaves from the top for each replicate, except top three leaves which were not fully expanded) were immersed in distilled water, and their weight was measured every $12 \mathrm{~h}$ until their weight no longer increased, and their saturated water concentration weight (Tw) was measured.

\subsection{Total Chlorophyll Content}

Chlorophyll concentration was estimated according to the method of Arnon et al. [42]. One g of fresh leaves were homogenized in $80 \%$ acetone $(1 \mathrm{~mL})$ and centrifuged for $20 \mathrm{~min}(1500 \mathrm{~g})$. After that supernatant was separated in a new tube and absorbance was recorded at wavelengths of 645 and $663 \mathrm{~nm}$.

\subsection{Antioxidant Enzyme Activity}

An aliquot of $500 \mathrm{mg}$ of fresh leaves was homogenized in $4.5 \mathrm{~mL}$ of phosphate buffer $(50 \mathrm{mM}$, $\mathrm{pH}$ 7.0) followed by centrifugation for $20 \mathrm{~min}\left(1500 \mathrm{~g}, 4^{\circ} \mathrm{C}\right)$. Supernatant was transferred to a separate tube and it was used as plant extract to determine the enzyme activities. The method Zhu et al. [43] was used to estimate SOD activity. The activity of ascorbate peroxidase (APX) was determined by the method of Jia et al. [44]. To determine activities of SOD and POD, we used two enzyme assay kits, 
following the instructions provided by the manufacturer. SOD assay kit number A001-2 and APX assay kit number A123 were provided by Nanjing Jiancheng Bioengineering Institute (Nanjing, China).

Catalase activity was determined according to Azevedo et al. [45]. One mL of phosphate buffer (50 mM, pH 7.0) was mixed with $2.5 \mu \mathrm{L}$ of hydrogen peroxide solution ( $30 \%$ ) followed by the addition of $15 \mu \mathrm{L}$ of supernatant (plant extract). Change in absorbance in the reaction mixture was recorded at $240 \mathrm{~nm}$.

\subsection{Malondialdehyde (MDA) and Proline (Pro) Concentration}

The concentration of MDA by-products was determined by the thiobarbituric acid method of Zhao et al. [46]. An aliquot of $500 \mathrm{mg}$ of fresh leaves was homogenized in $2.5 \mathrm{~mL}$ of trichloroacetic acid (TCA, $0.1 \%$ ). Crushed samples were centrifuged for $15 \mathrm{~min}\left(10,000 \mathrm{~g}, 4^{\circ} \mathrm{C}\right)$. The supernatant was separated and $0.5 \mathrm{~mL}$ of extract was mixed with $2 \mathrm{~mL}$ TCA $(20 \%)$, followed by incubation of reaction mixture at $95{ }^{\circ} \mathrm{C}(30 \mathrm{~min})$. Then, the mixture was kept in ice followed by centrifugation for $15 \mathrm{~min}$ at $10,000 \mathrm{~g}, 4^{\circ} \mathrm{C}$. Absorbance of supernatant was taken immediately at 532 and $600 \mathrm{~nm}$.

The concentration of Pro was estimated by the ninhydrin method by Bates et al. [47]. An aliquot of $500 \mathrm{mg}$ of fresh leaves was homogenized in $5 \mathrm{~mL}$ of aqueous sulfosalicylic acid (3\%) followed by filtration (Whatman $\mathrm{N}^{\circ} 1$ filter paper) of mixture. One $\mathrm{mL}$ of filtered extract was mixed with $1 \mathrm{~mL}$ each of acid-ninhydrin and glacial acetic acid followed by $1 \mathrm{~h}$ incubation in boiling water. After that, the reaction mixture was immediately placed in an ice bath, followed by the addition of $2 \mathrm{~mL}$ of toluene. The reaction mixture was used to record absorbance at $520 \mathrm{~nm}$.

\subsection{Quantitative Real-Time PCR}

Total RNA was extracted from $100 \mathrm{mg}$ of fresh leaves and $1 \mu \mathrm{g}$ of total RNA was used to synthesize cDNA using PrimeScript RT Master Mix (Takara). Expression of genes was estimated in the RT-PCR system C1000 Touch Thermal Cycler (Bio-Rad) using ChamQ SYBR qPCR Master Mix (Vazyme). Actin was used as a housekeeping and primer information is mentioned in Supplementary Table S1. The reaction consisted of total 45 cycles $\left(95^{\circ} \mathrm{C}\right.$ for $10 \mathrm{~s}$ followed by $57^{\circ} \mathrm{C}$ for $10 \mathrm{~s}$, and finally $72{ }^{\circ} \mathrm{C}$ for $20 \mathrm{~s}$ ). Expression change was determined by using formula $2^{-\Delta \Delta \mathrm{Ct}}$ [48]. All the experiments were done using three biological and technical replicates.

\subsection{Statistical Analysis}

The experiment was set up following a completely-randomized design. All data were subjected to Bartlett's test to assess homoscedasticity of data across populations. Data were subjected to one-way ANOVA and the means were then separated by the minimum significant difference (LSD) method $(p<0.05)$ using the SPSS-16 software. Graphs were plotted using the SIGMAPLOT 12.5. All the data presented are the mean \pm standard deviation of the three independent replicates.

\section{Results}

Drought stress resulted in severe toxic effects on the phenotype of Chinese hickory leaves at 30 days after treatment (DAT). However, melatonin pretreatment alleviated the drought-induced leaf damage (Figure 1).

Compared with control conditions, drought stress significantly reduced the RWC of leaves. Melatonin pre-treatment effectively alleviated the drought induced negative impact on RWC. (Figure 2A). At 30 DAT, RWC of leaves of drought stressed plants was significantly lower than that of the control group. Only slight (but significant) differences were recorded at 30 DAT between plants pre-treated and non-pre-treated with melatonin. RWC in the leaves of the M, M-P1, and M-P3 treatment groups increased by $8.14 \%, 10.29 \%$, and $14.68 \%$, compared with the CK, P1, and P3 treatment groups, respectively (30 DAT). Conversely, melatonin improved strongly the RWC of pre-treated plants (compared to the non-pre-treated) at seven and 21 DAT. 


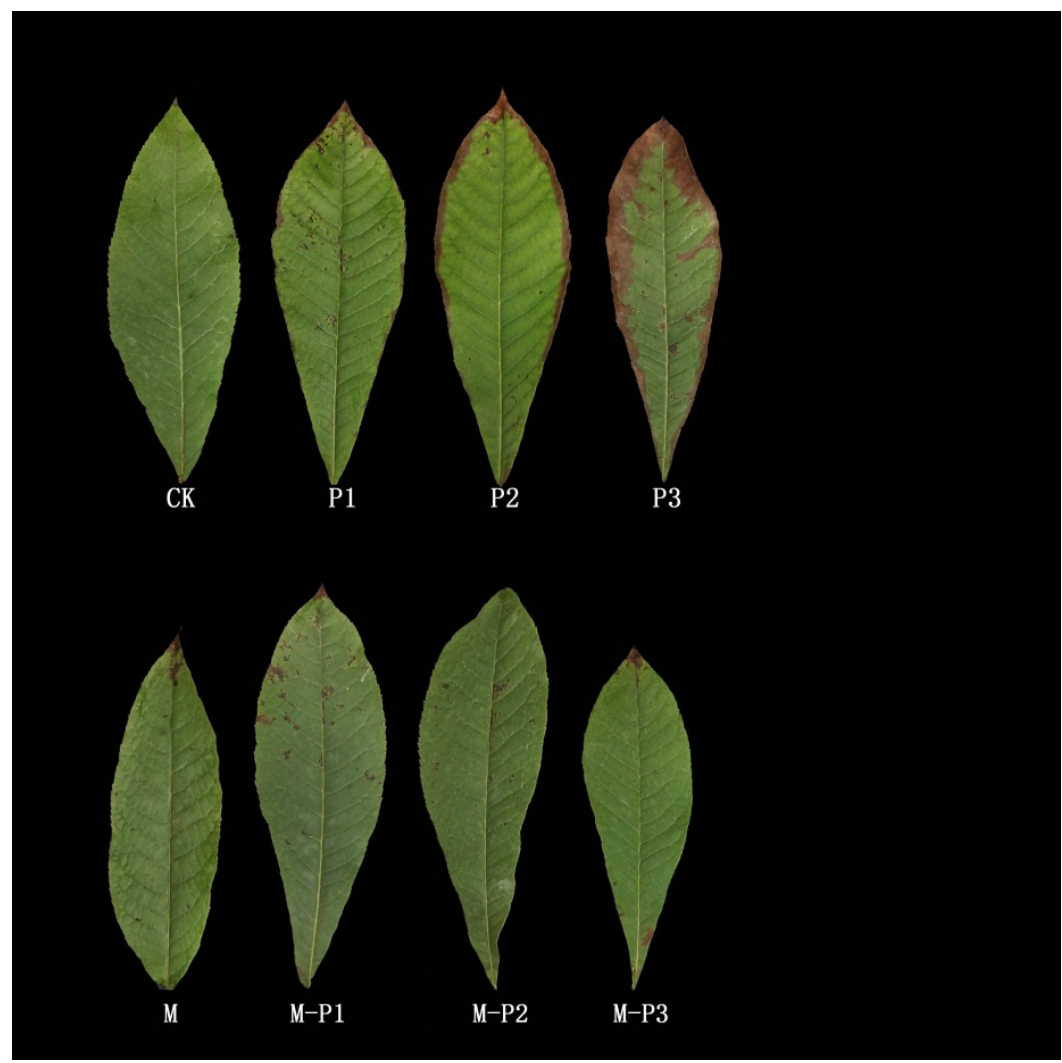

Figure 1. Effect of melatonin on Chinese hickory leaf phenotype and visible symptoms. Control (CK), 15\% polyethylene glycol (PEG) (P1), 25\% PEG (P2), 35\% PEG (P3), $100 \mu$ M melatonin (M), 15\% PEG + $100 \mu \mathrm{M}$ melatonin (M-P1), 25\% PEG + $100 \mu \mathrm{M}$ melatonin (M-P2), 35\% PEG + $100 \mu \mathrm{M}$ melatonin (M-P3).

In the absence of drought stress, the application of melatonin to the leaves of Chinese hickory improved the total chlorophyll concentration (Figure 2B). At $30 \mathrm{DAT}$, the total chlorophyll concentration in the M, M-P2, and M-P3 treatment groups was increased by $70.23 \%, 41.85 \%$, and $19.87 \%$, compared with the CK, P2, and P3 treatment groups, respectively.

Foliar application of melatonin effectively improved the values of Pn in Chinese hickory plants under drought stress, as well as in control plants (Figure 3A). At 30 DAT, the net photosynthetic rate of M-P1, M-P2, and M-P3 treatment groups was increased by $93.10 \%, 188.60 \%$, and $66.52 \%$, compared with P1, P2, and P3 treatment group, respectively. Melatonin spraying also increased the transpiration rate of leaves (Figure 3B). More effectiveness of melatonin application was observed at 21 DAT, where transpiration rate of M, M-P1, M-P2, and M-P3 treatment group was improved by $24.95 \%, 19.11 \%, 46.13 \%$, and $6.32 \%$, as compared to CK, P1, P2, and P3 treatment groups, respectively. The stomatal conductance of leaves was reduced under drought stress. However, application of melatonin recovered the stomatal conductance in plants subjected to drought stress (Figure 3C). At 30 DAT, stomatal conductance of M, M-P1, and M-P2 treatment group was increased by $115.70 \%$, $65.63 \%$, and $12.18 \%$, in comparison to that of $\mathrm{CK}, \mathrm{P} 1$, and $\mathrm{P} 2$ treatment groups, respectively, while in M-P3 it was reduced. At seven and 21 DAT, M-P1 and MP-2 showed a significant increase in stomatal conductance, whereas M-P3 showed no significant difference (Figure 3C). Drought stress lead to an increase in the concentration of intercellular $\mathrm{CO}_{2}$ in leaves, which was further reduced after melatonin application (Figure 3D). At 30 DAT, the intercellular $\mathrm{CO}_{2}$ concentration of M, M-P1, M-P2, and M-P3 groups was reduced by $6.07 \%, 10.04 \%$, and $17.33 \%$, in comparison to that of P1, P2, and P3 groups, respectively. 


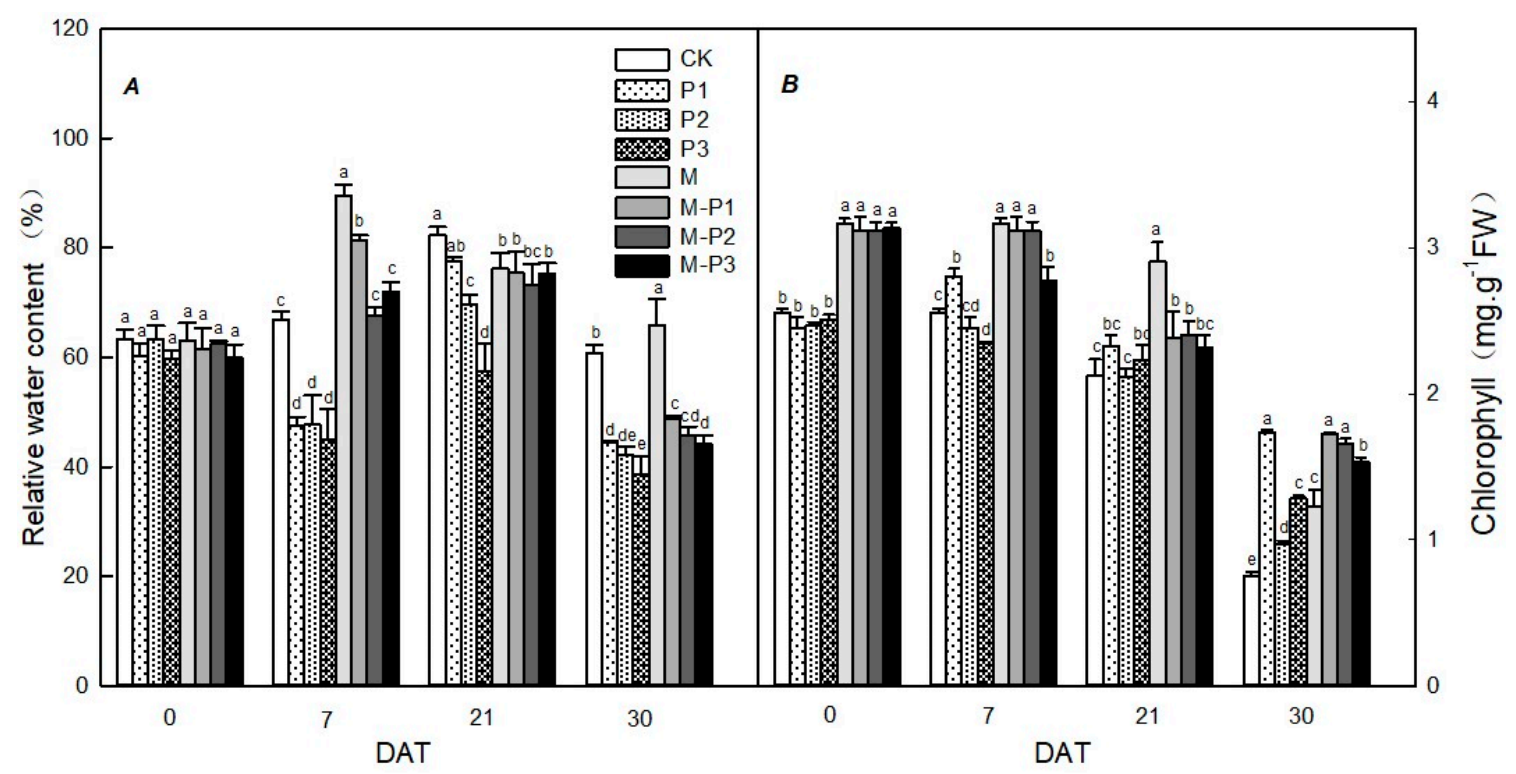

Figure 2. Effects of melatonin on relative water content (RWC) (A) and total chlorophyll (B) concentration. Each data point represents the mean \pm SD of three independent replicates. According to least significance difference (LSD) test, the mean values represented by different letters are significantly different $(p<0.05)$. Control (CK), 15\% PEG (P1), 25\% PEG (P2), 35\% PEG (P3), $100 \mu \mathrm{M}$ melatonin (M), 15\% PEG + $100 \mu \mathrm{M}$ melatonin (M-P1), 25\% PEG + $100 \mu \mathrm{M}$ melatonin (M-P2), 35\% PEG + $100 \mu \mathrm{M}$ melatonin (M-P3).

Values of WUE were improved after application of melatonin in drought-stressed plants (Figure 3E). The maximum recovery of WUE was observed in M-P2 (118.08\%) and M-P3 (192.91\%) groups when compared to the corresponding drought-stressed groups which were non-pretreated with melatonin, i.e., P2 and P3 (30 DAT). Additionally, melatonin application also improved Ls value in plants under drought conditions. It was observed that at $30 \mathrm{DAT}$, values of Ls were recovered by $16.53 \%$ (M-P1), $46.02 \%$ (M-P2), and $108.50 \%$ (M-P3) as compared to P1, P2, and P3 treatment groups, respectively (Figure 3F).

Short-term drought stress has little effect on values of Fv/Fm, but increasing the duration of drought, the damage to PSII was gradually increased as it was evident from the significant reduction of $\mathrm{Fv} / \mathrm{Fm}$ values. Melatonin application resulted in a recovery of $\mathrm{Fv} / \mathrm{Fm}$ values in drought-stressed plants (Figure 4A). Similarly, Y (II) also recovered in melatonin-treated drought-stressed plants. Compared with P1, P2, and P3, the Y (II) of M-P1, M-P2, and M-P3 groups was increased by $6.25 \%, 8.89 \%$, and $42.11 \%$, respectively (Figure $4 \mathrm{~B}$ ). Values of the ETR also increased with the application of melatonin. In M-P1, M-P2, and M-P3 groups, ETR was increased by $13.83 \%, 14.66 \%$, and $8.70 \%$, as compared with values of P1, P2, and P3 groups, respectively (Figure 4C). 


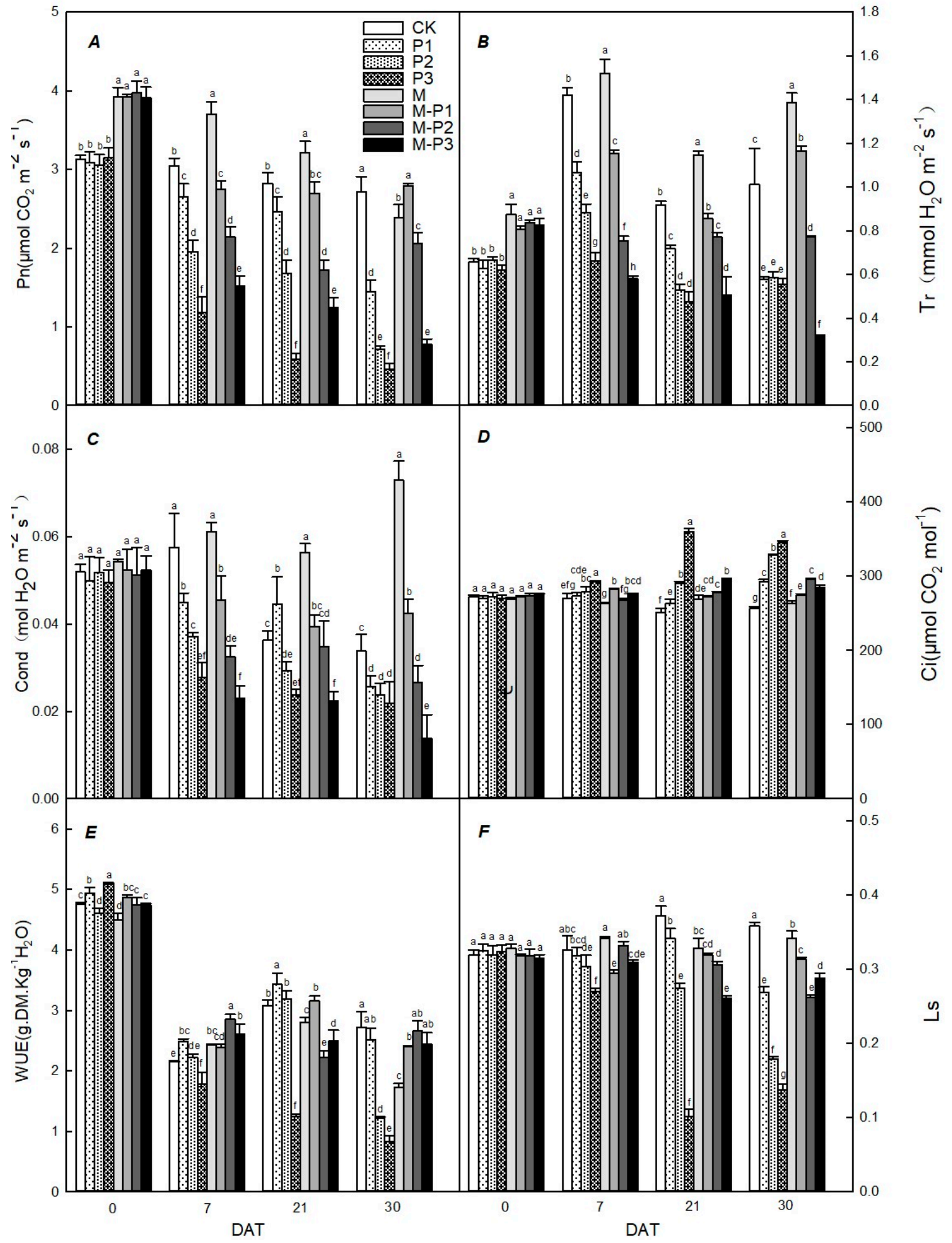

Figure 3. Effects of melatonin on gas exchange parameters in Chinese hickory leaves: Net photosynthetic rate $(\mathrm{Pn})(\mathbf{A})$, transpiration rate $(\mathrm{Tr})(\mathbf{B})$, stomatal conductance (Cond) $(\mathbf{C})$, intercellular $\mathrm{CO}_{2}$ concentration (Ci) (D), water use efficiency (WUE) (E), and stomatal restriction factors (Ls) (F). Each data point represents the mean \pm SD of three independent replicates. According to LSD test, the mean values represented by different letters are significantly different $(p<0.05)$. Control $(\mathrm{CK}), 15 \%$ PEG (P1), 25\% PEG (P2), 35\% PEG (P3), $100 \mu$ M melatonin (M), 15\% PEG + $100 \mu$ M melatonin (M-P1), 25\% PEG + $100 \mu \mathrm{M}$ melatonin (M-P2), 35\% PEG + $100 \mu \mathrm{M}$ melatonin (M-P3). 


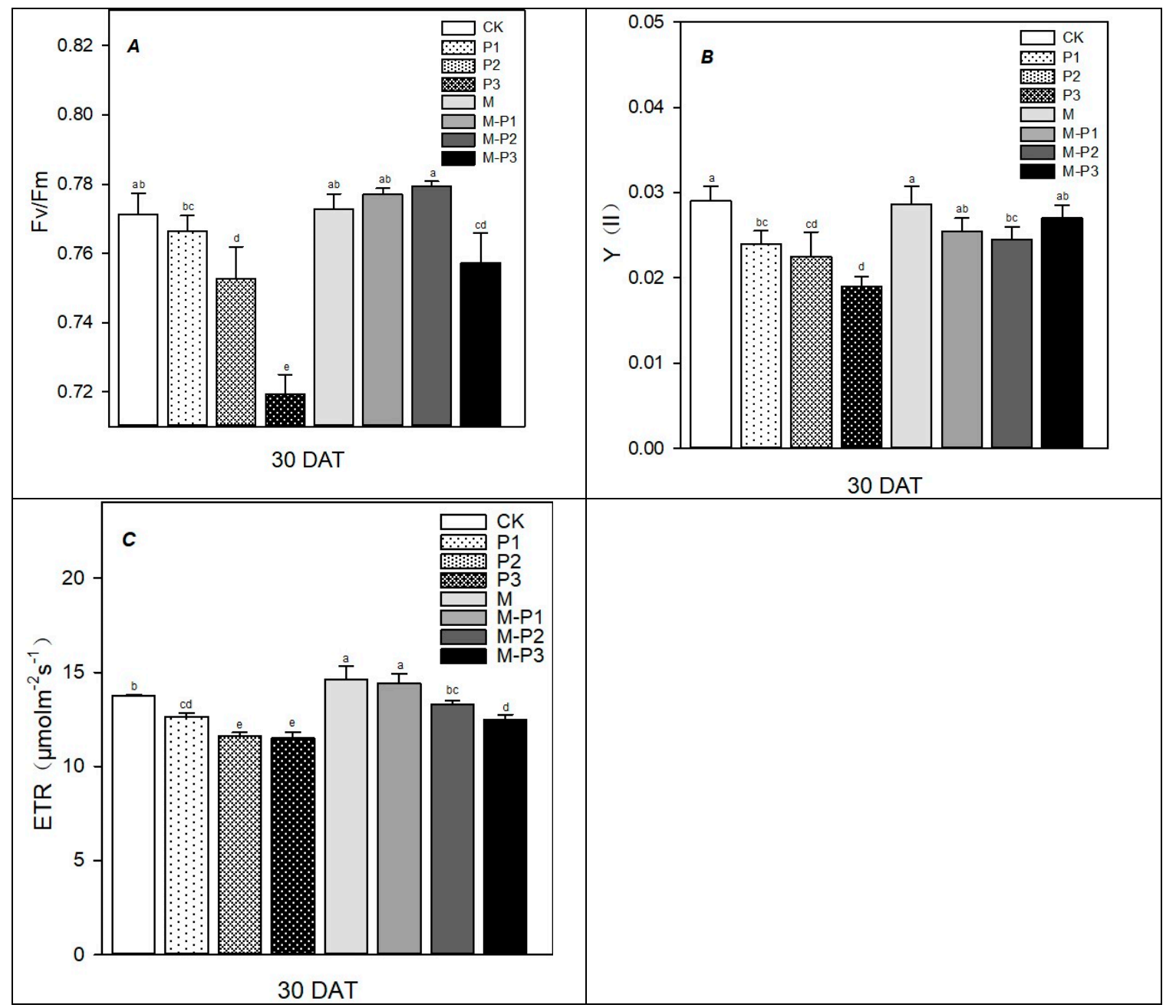

Figure 4. Effects of melatonin on photosystem II (PSII) photochemical efficiency (Fv/Fm; A), maximal photochemical efficiency (Y II; B) and electron transport rate (ETR; C) of leaves. Each data point represents the mean \pm SD of three independent replicates. According to LSD test, the mean values represented by different letters are significantly different $(p<0.05)$. Control (CK), 15\% PEG (P1), 25\% PEG (P2), 35\% PEG (P3), $100 \mu$ M melatonin (M), 15\% PEG + $100 \mu$ M melatonin (M-P1), 25\% PEG + $100 \mu \mathrm{M}$ melatonin (M-P2), 35\% PEG + $100 \mu \mathrm{M}$ melatonin (M-P3).

Compared with well-watered plants, the antioxidant enzyme activities (SOD, CAT, APX) in leaves were enhanced under drought stress, and the application of melatonin further enhanced the activities of the antioxidant enzymes measured in our experiment (Figure 5). At 21 DAT, change in SOD activity was maximum in M-P1 group (18.38\%) as compared to P1 group. The highest activity of POD was measured in melatonin-treated plants after seven DAT, where its activity was increased by $13.06 \%$ in M-P2 group as compared to P2 group. Similarly, the APX activity was also maximally increased in M-P2 group (31.86\%, 21 DAT) in comparison to that of P2 group. 


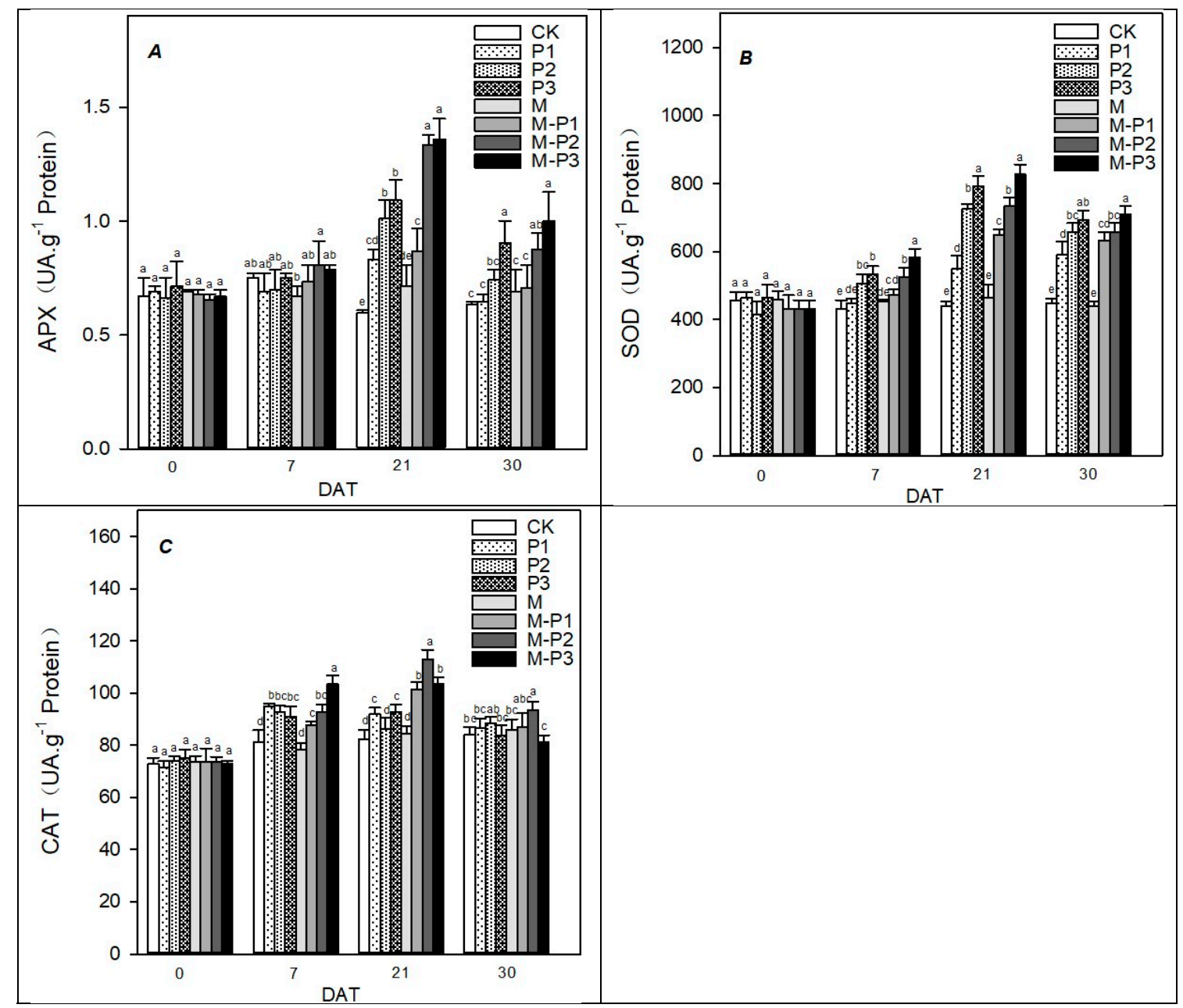

Figure 5. Effects of melatonin on the activity ascorbate peroxidase (APX); (A), superoxide dismutase SOD; $(B)$ and catalase (CAT; C) in leaves. Each data point represents the mean \pm SD of three independent replicates. According to LSD test, the mean values represented by different letters are significantly different $(p<0.05)$. Control (CK), 15\% PEG (P1), 25\% PEG (P2), 35\% PEG (P3), $100 \mu$ M melatonin (M), 15\% PEG + $100 \mu \mathrm{M}$ melatonin (M-P1), 25\% PEG + $100 \mu \mathrm{M}$ melatonin (M-P2), 35\% PEG + $100 \mu \mathrm{M}$ melatonin (M-P3).

The relative expression of $A P X, S O D$, and $C A T$ genes was observed to be up-regulated in melatonin pre-treated Chinese hickory plants growing under drought stress (30 DAT). The maximum up-regulation in the expression levels was noticed in M-P1 group as compared to corresponding P1 treatment group (Figure 6). The gene expression was up-regulated by $66.50 \%, 70.74 \%$, and $32.7 \%$ for APX (Figure 6A), SOD (Figure 6B), and CAT (Figure 6C), respectively, when P1 treatment group was compared with M-P1 treatment group. 


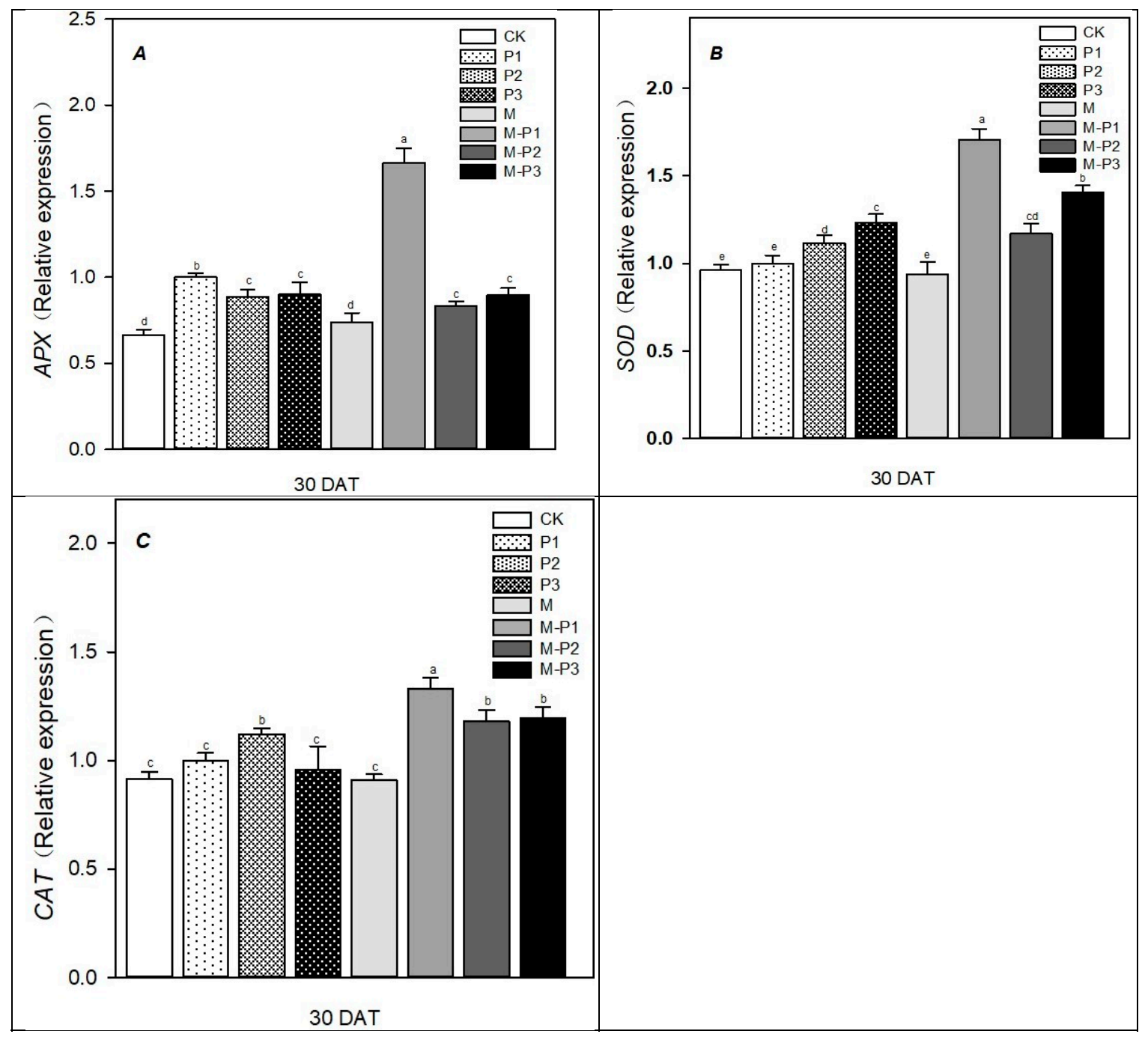

Figure 6. Impact of melatonin on the relative expression of genes encoding ascorbate peroxidase (APX); (A), superoxide dismutase $(S O D ; \mathbf{B})$ and catalase $(C A T ; \mathbf{C})$ in Chinese hickory leaves. Data represents the mean \pm SD of three independent replicates. Mean values with different letters are significantly different from each other $(p<0.05)$. Control (CK), 15\% PEG (P1), 25\% PEG (P2), 35\% PEG (P3), $100 \mu \mathrm{M}$ melatonin (M), 15\% PEG + $100 \mu \mathrm{M}$ melatonin (M-P1), 25\% PEG + $100 \mu$ M melatonin (M-P2), 35\% PEG $+100 \mu \mathrm{M}$ melatonin (M-P3).

It was observed that drought stress increased MDA and proline concentration in the leaves. Of note, melatonin pre-treatment reduced the levels of MDA by-products accumulation and increased the proline concentration (Figure 7). The concentration of MDA at 21 DAT was maximum reduced by $11.91 \%$ in M-P2 group as compared to P2 group (Figure 7A). Proline concentration was also noticed to increase maximum in M-P2 group (32.63\%, at seven DAT) as compared to moderate drought stress group (P2) (Figure 7B). 


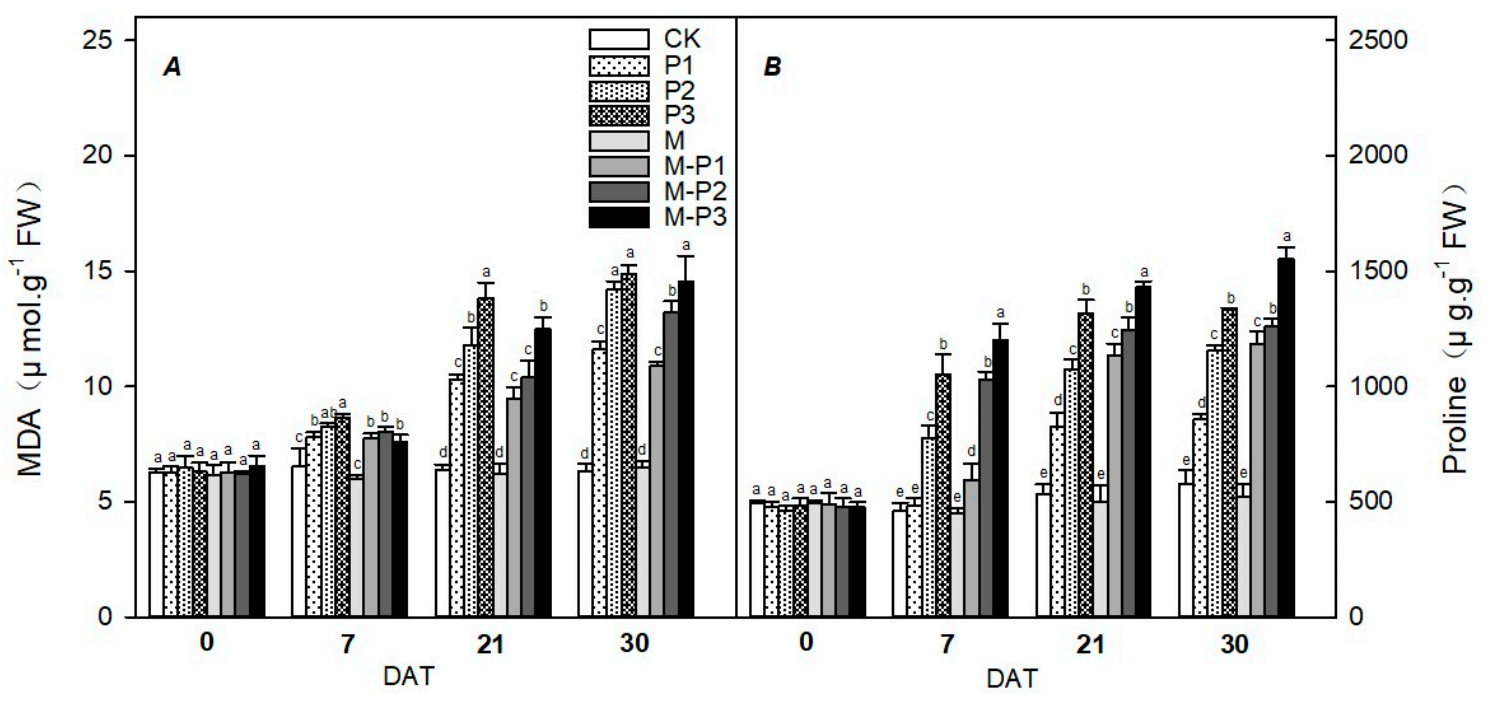

Figure 7. Effects of melatonin on malondialdehyde (MDA) (A) and proline (B) in Chinese hickory leaves. Each data point represents the mean \pm SD of three independent samples. According to LSD test, the mean values represented by different letters are significantly different $(p<0.05)$. Control (CK), 15\% PEG (P1), 25\% PEG (P2), 35\% PEG (P3), $100 \mu$ M melatonin (M), 15\% PEG + $100 \mu$ M melatonin (M-P1), 25\% PEG + $100 \mu \mathrm{M}$ melatonin (M-P2), 35\% PEG + $100 \mu \mathrm{M}$ melatonin (M-P3).

\section{Discussion}

Drought is one of the most common abiotic stresses, which affects seed germination, plant growth, metabolism, and overall the plant yield. In the present study, drought stress seriously altered the leaf status by reduced RWC and total chlorophyll concentration of Chinese hickory leaves. Melatonin pretreatment ameliorated the effect of drought as evident by lower impairment of RWC and chlorophyll concentration, which might be due to the regulation of water balance and less degradation of chlorophylls [31,49].

In the present study, melatonin pre-treatment efficiently improved Pn with respect to drought stressed plants which were not treated with melatonin. Principally, melatonin limits stomata limitations and preserve the transpiration rate of Chinese hickory leaves. Additionally, melatonin is also observed to preserve from non-stomata limitation, thereby protecting PSII from the adverse effects of drought, according to other researches [31,49]. Moreover, under drought stress, plants improve their WUE in the attempt to limit their water loss [50,51], which is consistent with the results of present study. We found indeed that the levels of WUE in melatonin pre-treated Chinese hickory leaves were improved under drought conditions.

The process of photosynthesis is affected by stomatal opening and intracellular environment, and drought stress caused both stomatal and non-stomatal limitations [52]. Stomatal limitations can reduce the intercellular carbon dioxide concentration of the leaves by reducing the stomatal opening and, in turn, reducing the photosynthetic yield of plants. Among other biochemical limitations, photosystem II is the most vulnerable part of photosynthetic apparatus when the plants are subjected to environmental cues, such as drought conditions [53,54]. In the present study, reduction of Fv/Fm, Y II, and ETR were observed under drought stress. Of note, melatonin pre-treatment resulted in a lower impact of drought to those PSII parameters. This improvement after melatonin treatment might be due to the protection of chloroplast structure from drought-induced injuries [55]. Drought stress causes imbalance in ROS metabolism [56], and excessive accumulation of ROS leads to membrane peroxidation, chlorophyll degradation, and reduced photosynthetic performance of plants [49]. Antioxidant defense systems can counteract excessive ROS production in plants to protect them from oxidative damage [57]. Melatonin can directly scavenge $\mathrm{hyH}_{2} \mathrm{O}_{2}$ in plant cells [58] by up-regulating the gene expression of key antioxidant enzymes under stress [59] along with stimulating the activities of antioxidant 
enzymes [60]. In the current investigation, the activity of SOD, POD, and APX increased under drought stress, and their activities were further triggered in melatonin-pretreated plants. This was effectively supporting for a stimulating activity by melatonin to antioxidant enzymes. The enhancement of antioxidant enzymes was also associated with the melatonin-mediated up-regulation of transcript levels of genes encoding for APX, SOD, and CAT, which is in agreement with previous findings [61].

As a common osmotic regulator and antioxidant in plants, the increase of proline content under stress is considered to be the main way to improve the resistance of plants [23,62], and the content of proline under stress is often an indicator of the tolerance of plants to stress [63]. In the present study, MDA and proline levels in plants were increased under drought stress, indicating that the membrane lipid peroxidation of plant cells was increased under drought stress, and the stress resistance of plants to drought was gradually improved by accumulation of proline. After treatment with melatonin, MDA by-products levels decreased, while proline accumulation further accumulated. Melatonin reduces membrane lipid peroxidation in plants by increasing antioxidant capacity [27]. Moreover, enhanced proline accumulation may be due to a direct regulation of proline biosynthesis triggered by melatonin at biochemical and molecular level $[32,64]$.

\section{Conclusions}

This study showed that drought stress significantly reduced photosynthetic capacity of Chinese hickory plants, and long-term drought can damage the PSII. Melatonin spraying promotes the enhancement of the antioxidative enzymatic system in Chinese hickory plants under drought stress, thus ameliorating the redox balance and preserving the leaf physiological status. Results of the present experiment highlight the possibility of using a melatonin-based pre-treatment in Chinese hickory to enhance the performances of this widely cultivated and economically-important tree species in China when subjected to limited water availability.

Supplementary Materials: The following are available online at http://www.mdpi.com/2073-4395/9/11/702/s1, Table S1: Primers used for gene expression analysis.

Author Contributions: Conceptualization, B.Z., H.Y., and D.Y.; Methodology, investigation, formal analysis, J.W., J.C., A.S., and S.T.; Resources, B.Z., H.Y., and D.Y.; Writing original draft, J.W. and A.S.; Writing-review and editing, A.S., B.Z., H.Y., M.L., and D.Y.

Funding: We acknowledge the different funding agencies: This study was supported by the National Key Research and Development Program of China (2018YFD1000600, 2018YFD1000604); Key Project of Zhejiang Provincial Natural Science Foundation (LZ18C160001); National Natural Science Foundation of China (31901346, 31971695, 31470683, 31270716, and 31070604); Independent Research Project of State Key Laboratory of Subtropical Silviculture, Zhejiang A\&F University (ZY20180208, ZY20180308); Open Foundation of State Key Laboratory of Subtropical Silviculture, Zhejiang A\&F University (KF201708); Overseas Expertise Introduction Project for Discipline Innovation (111 Project D18008); Key Research and Development Program of Zhejiang Province (2018C02004); National High Technology Research and Development Program of China (863 Program) (2013AA102605); Fruit Innovation Team Project of Zhejiang Province (2016C02052-12); Key Agricultural New Varieties Breeding Projects founded by Zhejiang Province Science and Technology Department (2016C02052-13); Zhejiang Provincial Natural Science Foundation for Distinguished Young Scholar (LR13C160001); Open Foundation of First-class Discipline of Forestry, Zhejiang Province (201703); The First-class General Financial Grant from the China Postdoctoral Science Foundation (2017M610377).

Conflicts of Interest: The authors declare no conflict of interest.

\section{References}

1. Yuan, H.; Zhao, L.; Chen, J.; Yang, Y.; Xu, D.; Tao, S.; Zheng, S.; Shen, Y.; He, Y.; Shen, C. Identification and expression profiling of the Aux/IAA gene family in Chinese hickory ( Carya cathayensis Sarg.) during the grafting process. Plant Physiol. Biochem. 2018, 127, 55-63. [CrossRef] [PubMed]

2. $\mathrm{Xu}$, Q.; Wu, J.; Cao, Y.; Yang, X.; Wang, Z.; Huang, J.; Xia, G.; Zhang, Q.; Hu, Y. Photosynthetic characteristics of leaves and fruits of Hickory (Carya cathayensis Sarg.) and Pecan (Carya illinoensis K.Koch) during fruit development stages. Trees 2016, 30, 1523-1534. [CrossRef]

3. Naresh, P.S.; Pramod, K.P.; Sandeep, K.V. Morpho-physiological characterization of Indian wheat genotypes and their evaluation under drought condition. Afr. J. Biotechnol. 2014, 13, 2022-2027. [CrossRef] 
4. Tanveer, M.; Shahzad, B.; Sharma, A.; Khan, E.A. 24-Epibrassinolide application in plants: An implication for improving drought stress tolerance in plants. Plant Physiol. Biochem. 2019, 135, 295-303. [CrossRef]

5. Shivakrishna, P.; Reddy, K.A.; Rao, D.M. Effect of PEG-6000 Imposed drought stress on RNA content, Relative water content (RWC), and Chlorophyll content in peanut leaves and roots. Saudi J. Biol. Sci. 2018, 25, 285.

6. Karamanos, A.J. Water stress and leaf growth of field beans (Vicia faba L.) in the field: Leaf number and total leaf area. Ann. Bot. 1978, 42, 1393-1402. [CrossRef]

7. Chaves, M.M. Effects of Water Deficits on Carbon Assimilation. J. Exp. Bot. 1991, 42, 1-16. [CrossRef]

8. Flexas, J.; Bota, J.; Loreto, F.; Cornic, G.; Sharkey, T.D. diffusive and metabolic limitations to photosynthesis under drought and salinity in C3 Plants. Plant Biol. 2004, 6, 269-279. [CrossRef]

9. Chaves, M.M. Mechanisms underlying plant resilience to water deficits: Prospects for water-saving agriculture. J. Exp. Bot. 2004, 55, 2365-2384. [CrossRef]

10. Aruoma, O.; Halliwell, B.; J Laughton, M.; Quinlan, G.; Gutteridge, J.M.C. The Mechanism of Initiation of Lipid Peroxidation. Evidence against a Requirement for an Iron (II)-Iron (III) Complex. Biochem. J. 1989, 258, 617-620. [CrossRef]

11. Kaur, P.; Bali, S.; Sharma, A.; Kohli, S.K.; Vig, A.P.; Bhardwaj, R.; Thukral, A.K.; Abd-Allah, E.F.; Wijaya, L.; Alyemeni, M.N. Cd induced generation of free radical species in Brassica juncea is regulated by supplementation of earthworms in the drilosphere. Sci. Total Environ. 2019, 655, 663-675. [CrossRef] [PubMed]

12. Shahzad, B.; Tanveer, M.; Rehman, A.; Cheema, S.A.; Fahad, S.; Rehman, S.; Sharma, A. Nickel; whether toxic or essential for plants and environment-A review. Plant Physiol. Biochem. 2018, 132, 641-651. [CrossRef] [PubMed]

13. Sharma, A.; Kumar, V.; Kanwar, M.; Thukral, A.; Bhardwaj, R. Ameliorating imidacloprid induced oxidative stress by 24-epibrassinolide in Brassica juncea L. Russ. J. Plant Physiol. 2017, 64, 509-517. [CrossRef]

14. Cruz de Carvalho, M.H. Drought stress and reactive oxygen species: Production, scavenging and signaling. Plant Signal. Behav. 2008, 3, 156-165. [CrossRef] [PubMed]

15. Jaleel, C.A.; Riadh, K.; Gopi, R.; Manivannan, P.; Ines, J.; Al-Juburi, H.J.; Chang-Xing, Z.; Hong-Bo, S.; Panneerselvam, R. Antioxidant defense responses: Physiological plasticity in higher plants under abiotic constraints. Acta Physiol. Plant. 2009, 31, 427-436. [CrossRef]

16. Gill, S.S.; Tuteja, N. Reactive oxygen species and antioxidant machinery in abiotic stress tolerance in crop plants. Plant Physiol. Biochem. 2010, 48, 909-930. [CrossRef]

17. Semane, B.; Cuypers, A.; Smeets, K.; Van Belleghem, F.; Horemans, N.; Schat, H.; Vangronsveld, J. Cadmium responses in Arabidopsis thaliana: Glutathione metabolism and antioxidative defence system. Physiol. Plant. 2007, 129, 519-528. [CrossRef]

18. Sofo, A.; Scopa, A.; Nuzzaci, M.; Vitti, A. Ascorbate peroxidase and catalase activities and their genetic regulation in plants subjected to drought and salinity stresses. Int. J. Mol. Sci. 2015, 16, 13561-13578. [CrossRef]

19. Sharma, A.; Kumar, V.; Kumar, R.; Shahzad, B.; Thukral, A.K.; Bhardwaj, R. Brassinosteroid-mediated pesticide detoxification in plants: A mini-review. Cogent Food Agric. 2018, 4, 1436212. [CrossRef]

20. Alonso, R.; Elvira, S.; Castillo, F.; Gimeno, B. Interactive effects of ozone and drought stress on pigments and activities of antioxidative enzymes in Pinus halepensis. Plant Cell Environ. 2001, 24, 905-916. [CrossRef]

21. Silva, E.N.; Ribeiro, R.V.; Ferreira-Silva, S.L.; Vieira, S.A.; Ponte, L.F.; Silveira, J.A. Coordinate changes in photosynthesis, sugar accumulation and antioxidative enzymes improve the performance of Jatropha curcas plants under drought stress. Biomass Bioenergy 2012, 45, 270-279. [CrossRef]

22. Lu, S.; Su, W.; Li, H.; Guo, Z. Abscisic acid improves drought tolerance of triploid bermudagrass and involves $\mathrm{H}_{2} \mathrm{O}_{2}$-and NO-induced antioxidant enzyme activities. Plant Physiol. Biochem. 2009, 47, 132-138. [CrossRef] [PubMed]

23. Sharma, A.; Shahzad, B.; Kumar, V.; Kohli, S.K.; Sidhu, G.P.S.; Bali, A.S.; Handa, N.; Kapoor, D.; Bhardwaj, R.; Zheng, B. Phytohormones regulate accumulation of osmolytes under abiotic stress. Biomolecules 2019, 9, 285. [CrossRef] [PubMed]

24. Tarkow, H.; Feist, W.C.; Southerland, C.F. Interaction of wood with polymeric materials. Penetration versus molecular size. For. Prod. J. 1966, 16, 61-65.

25. Emmerich, W.E.; Hardegree, S.P. Polyethylene glycol solution contact effects on seed germination. Agron. J. 1990, 82, 1103-1107. [CrossRef] 
26. Zhang, N.; Sun, Q.; Zhang, H.; Cao, Y.; Weeda, S.; Ren, S.; Guo, Y.-D. Roles of melatonin in abiotic stress resistance in plants. J. Exp. Bot. 2015, 66, 647-656. [CrossRef]

27. Sharma, A.; Zheng, B. Melatonin mediated regulation of drought stress: Physiological and molecular aspects. Plants 2019, 8, 190. [CrossRef]

28. Sarropoulou, V.N.; Therios, I.N.; Dimassi-Theriou, K.N. Melatonin promotes adventitious root regeneration in in vitro shoot tip explants of the commercial sweet cherry rootstocks CAB-6P (Prunus cerasus L.), Gisela 6 (P. cerasus $\times$ P. canescens), and MxM 60 (P. avium $\times$ P. mahaleb). J. Pineal Res. 2012, 52, 38-46. [CrossRef]

29. Li, C.; Wang, P.; Wei, Z.; Liang, D.; Liu, C.; Yin, L.; Jia, D.; Fu, M.; Ma, F. The mitigation effects of exogenous melatonin on salinity-induced stress in Malus hupehensis. J. Pineal Res. 2012, 53, 298-306. [CrossRef]

30. Kostopoulou, Z.; Therios, I.; Roumeliotis, E.; Kanellis, A.K.; Molassiotis, A. Melatonin combined with ascorbic acid provides salt adaptation in Citrus aurantium L. seedlings. Plant Physiol. Biochem. 2015, 86, 155-165. [CrossRef]

31. Zhang, N.; Zhao, B.; Zhang, H.J.; Weeda, S.; Yang, C.; Yang, Z.C.; Ren, S.; Guo, Y.D. Melatonin promotes water-stress tolerance, lateral root formation, and seed germination in cucumber (Cucumis sativus L.). J. Pineal Res. 2012, 54, 15-23. [CrossRef] [PubMed]

32. Antoniou, C.; Chatzimichail, G.; Xenofontos, R.; Pavlou, J.J.; Panagiotou, E.; Christou, A.; Fotopoulos, V. Melatonin systemically ameliorates drought stress-induced damage in Medicago sativa plants by modulating nitro-oxidative homeostasis and proline metabolism. J. Pineal Res. 2017, 62, e12401. [CrossRef] [PubMed]

33. Shu, H.H.; Chun, C.W.; Ivanov, S.V.; Alexieva, V.; Chih, W.Y. Repetition of hydrogen peroxide treatment induces a chilling tolerance comparable to cold acclimation in mung bean. J. Am. Soc. Hortic. Sci. 2007, 132, 770-776.

34. Moussa, H.R.; Algamal, S.M.A. Does Exogenous application of melatonin ameliorate boron toxicity in spinach plants? Int. J. Veg. Sci. 2017, 23, 233-245. [CrossRef]

35. Sarafi, E.; Tsouvaltzis, P.; Chatzissavvidis, C.; Siomos, A.; Therios, I. Melatonin and resveratrol reverse the toxic effect of high boron (B) and modulate biochemical parameters in pepper plants (Capsicum annuum L.). Plant Physiol. Biochem. 2017, 112, 173-182. [CrossRef]

36. Tan, D.X. Phytoremediative Capacity of Plants Enriched with Melatonin. Plant Signal. Behav. 2007, 2, 514-516. [CrossRef]

37. Zhao, Y.; Qi, L.W.; Wang, W.M.; Saxena, P.K.; Liu, C.Z. Melatonin improves the survival of cryopreserved callus of Rhodiola crenulata. J. Pineal Res. 2011, 50, 83-88. [CrossRef]

38. García, J.J.; López-Pingarrón, L.; Almeida-Souza, P.; Tres, A.; Escudero, P.; García-Gil, F.A.; Tan, D.X.; Reiter, R.J.; Ramírez, J.M.; Bernal-Pérez, M. Protective effects of melatonin in reducing oxidative stress and in preserving the fluidity of biological membranes: A review. J. Pineal Res. 2014, 56, 225-237. [CrossRef]

39. Allegra, M.; Reiter, R.J.; Tan, D.X.; Gentile, C.; Tesoriere, L.; Livrea, M.A. The chemistry of melatonin's interaction with reactive species. J. Pineal Res. 2010, 34, 1-10. [CrossRef]

40. Li, X.; Wei, J.P.; Scott, E.R.; Liu, J.W.; Guo, S. Exogenous melatonin alleviates cold stress by promoting antioxidant defense and redox homeostasis in Camellia sinensis L. Molecules 2018, 23, 165. [CrossRef]

41. Sionit, N.; Mortensen, D.; Strain, B.; Hellmers, H. Growth response of wheat to $\mathrm{CO}_{2}$ enrichment and different levels of mineral nutrition. Agron. J. 1981, 73, 1023-1027. [CrossRef]

42. Arnon, D.I. Copper enzymes in isolated chloroplasts. Polyphenoloxidase in Beta vulgaris. Plant Physiol. 1949, 24, 1-15. [CrossRef] [PubMed]

43. Zhu, X.; Hou, L.; Zhang, J.; Yao, C.; Liu, Y.; Zhang, C.; Xu, Y.; Cao, J. The structural and functional effects of fine particulate matter from cooking oil fumes on rat umbilical cord blood vessels. Environ. Sci. Poll. Res. 2016, 23, 16567-16578. [CrossRef] [PubMed]

44. Jia, X.; Wang, S.; Zhou, L.; Sun, L. The potential liver, brain, and embryo toxicity of titanium dioxide nanoparticles on mice. Nanoscale Res. Lett. 2017, 12, 478. [CrossRef]

45. Azevedo, R.; Alas, R.; Smith, R.; Lea, P. Response of antioxidant enzymes to transfer from elevated carbon dioxide to air and ozone fumigation, in the leaves and roots of wild-type and a catalase-deficient mutant of barley. Physiol. Plant. 1998, 104, 280-292. [CrossRef]

46. Zhao, S.J.; Xu, C.C.; Zou, Q.; Meng, Q.W. Improvements of method for measurement of malondialdehyde in plant tissues. Plant Physiol. Commun. 1994, 30, 207-210.

47. Bates, L.S.; Waldren, R.P.; Teare, I.D. Rapid determination of free proline for water-stress studies. Plant Soil 1973, 39, 205-207. [CrossRef] 
48. Livak, K.J.; Schmittgen, T.D. Analysis of relative gene expression data using real-time quantitative PCR and the $2^{-\Delta \Delta C T}$ method. Methods 2001, 25, 402-408. [CrossRef]

49. Ye, J.; Wang, S.; Deng, X.; Yin, L.; Xiong, B.; Wang, X. Melatonin increased maize (Zea maysL.) seedling drought tolerance by alleviating drought-induced photosynthetic inhibition and oxidative damage. Acta Physiol. Plant. 2016, 38, 48. [CrossRef]

50. Nativ, R.; Ephrath, J.E.; Berliner, P.R.; Saranga, Y. Drought resistance and water use efficiency in Acacia saligna. Aus. J. Bot. 1999, 47, 577-586. [CrossRef]

51. Zhang, S.Y.; Zhang, G.C.; Gu, S.Y.; Xia, J.B.; Zhao, J.K. Critical responses of photosynthetic efficiency of goldspur apple tree to soil water variation in semiarid loess hilly area. Photosynthetica 2010, 48, 589-595. [CrossRef]

52. Farquhar, G.D.; Sharkey, T.D. Stomatal conductance and photosynthesis. Annu. Rev. Plant Physiol. 1982, 33, 317-345. [CrossRef]

53. Maxwell, K. Chlorophyll fluorescence-A practical guide. J Exp. Bot. 2000, 51, 659-668. [CrossRef] [PubMed]

54. Woo, N.S.; Badger, M.R.; Pogson, B.J. A rapid, non-invasive procedure for quantitative assessment of drought survival using chlorophyll fluorescence. Plant Met. 2008, 4, 27. [CrossRef]

55. Meng, J.F.; Xu, T.F.; Wang, Z.Z.; Fang, Y.L.; Xi, Z.M.; Zhang, Z.W. The ameliorative effects of exogenous melatonin on grape cuttings under water-deficient stress: Antioxidant metabolites, leaf anatomy, and chloroplast morphology. J. Pineal Res. 2014, 57, 200-212. [CrossRef]

56. Gong, H.; Zhu, X.; Chen, K.; Wang, S.; Zhang, C. Silicon alleviates oxidative damage of wheat plants in pots under drought. Plant Sci. 2005, 169, 313-321. [CrossRef]

57. Souza, T.C.D.; Magalhães, P.C.; Castro, E.M.D.; Carneiro, N.P.; Padilha, F.A.; Júnior, C.C.G. ABA application to maize hybrids contrasting for drought tolerance: Changes in water parameters and in antioxidant enzyme activity. Plant Growth Regul. 2014, 73, 205-217. [CrossRef]

58. Tan, D.X.; Manchester, L.C.; Reiter, R.J.; Plummer, B.F.; Qi, W. Melatonin directly scavenges hydrogen peroxide: A potentially new metabolic pathway of melatonin biotransformation. Free Rad. Biol. Med. 2000, 29, 1177-1185. [CrossRef]

59. Takahashi, S.; Murata, N. How do environmental stresses accelerate photoinhibition? Trends Plant Sci. 2008, 13, 178-182. [CrossRef]

60. Schmutz, J.; Cannon, S.B.; Schlueter, J.; Ma, J.; Mitros, T.; Nelson, W.; Hyten, D.L.; Song, Q.; Thelen, J.J.; Cheng, J. Genome sequence of the palaeopolyploid soybean. Nature 2010, 463, 178-183. [CrossRef]

61. Cui, G.; Zhao, X.; Liu, S.; Sun, F.; Zhang, C.; Xi, Y. Beneficial effects of melatonin in overcoming drought stress in wheat seedlings. Plant Physiol. Biochem. 2017, 118, 138-149. [CrossRef] [PubMed]

62. Verbruggen, N.; Hermans, C. Proline accumulation in plants: A review. Amino Acids 2008, 35, 753-759. [CrossRef] [PubMed]

63. Jaleel, C.A.; Gopi, R.; Sankar, B.; Manivannan, P.; Kishorekumar, A.; Sridharan, R.; Panneerselvam, R. Studies on germination, seedling vigour, lipid peroxidation and proline metabolism in Catharanthus roseus seedlings under salt stress. South Afr. J. Bot. 2007, 73, 190-195. [CrossRef]

64. Sarropoulou, V.; Dimassi-Theriou, K.; Therios, I.; Koukourikou-Petridou, M. Melatonin enhances root regeneration, photosynthetic pigments, biomass, total carbohydrates and proline content in the cherry rootstock PHL-C (Prunus avium $\times$ Prunus cerasus). Plant Physiol. Biochem. 2012, 61, 162-168. [CrossRef] [PubMed]

(C) 2019 by the authors. Licensee MDPI, Basel, Switzerland. This article is an open access article distributed under the terms and conditions of the Creative Commons Attribution (CC BY) license (http://creativecommons.org/licenses/by/4.0/). 